February 2005 - NREL/CP-520-36565

\title{
Closed-Form Solutions and Parameterization of the Problem of Current-Voltage Performance of Polycrystalline Photovoltaic Modules Deployed at Fixed Latitude Tilt
}

J.A. del Cueto

Prepared for the $31^{\text {st }}$ IEEE Photovoltaics Specialists Conference and Exhibition Lake Buena Vista, Florida January 3-7, 2005
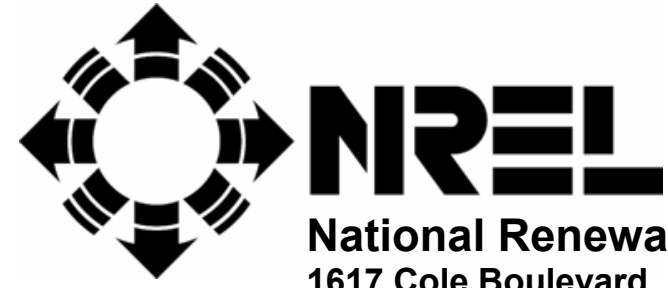

National Renewable Energy Laboratory 1617 Cole Boulevard, Golden, Colorado 80401-3393 303-275-3000 • www.nrel.gov

Operated for the U.S. Department of Energy Office of Energy Efficiency and Renewable Energy by Midwest Research Institute • Battelle 


\section{NOTICE}

The submitted manuscript has been offered by an employee of the Midwest Research Institute (MRI), a contractor of the US Government under Contract No. DE-AC36-99G010337. Accordingly, the US Government and MRI retain a nonexclusive royalty-free license to publish or reproduce the published form of this contribution, or allow others to do so, for US Government purposes.

This report was prepared as an account of work sponsored by an agency of the United States government. Neither the United States government nor any agency thereof, nor any of their employees, makes any warranty, express or implied, or assumes any legal liability or responsibility for the accuracy, completeness, or usefulness of any information, apparatus, product, or process disclosed, or represents that its use would not infringe privately owned rights. Reference herein to any specific commercial product, process, or service by trade name, trademark, manufacturer, or otherwise does not necessarily constitute or imply its endorsement, recommendation, or favoring by the United States government or any agency thereof. The views and opinions of authors expressed herein do not necessarily state or reflect those of the United States government or any agency thereof.

Available electronically at http://www.osti.gov/bridge

Available for a processing fee to U.S. Department of Energy and its contractors, in paper, from:

U.S. Department of Energy

Office of Scientific and Technical Information

P.O. Box 62

Oak Ridge, TN 37831-0062

phone: 865.576 .8401

fax: 865.576.5728

email: mailto:reports@adonis.osti.gov

Available for sale to the public, in paper, from:

U.S. Department of Commerce

National Technical Information Service

5285 Port Royal Road

Springfield, VA 22161

phone: 800.553 .6847

fax: 703.605.6900

email: orders@ntis.fedworld.gov

online ordering: http://www.ntis.gov/ordering.htm 


\title{
CLOSED-FORM SOLUTIONS AND PARAMETERIZATION OF THE PROBLEM OF CURRENT-VOLTAGE PERFORMANCE OF POLYCRYSTALLINE PHOTOVOLTAIC MODULES DEPLOYED AT FIXED LATITUDE TILT
}

\author{
J.A. del Cueto, National Renewable Energy Laboratory (NREL), 1617 Cole Boulevard, Golden, CO 80401, USA
}

\begin{abstract}
One obstacle to wider market penetration for thin-film polycrystalline photovoltaic (PV) modules is the lack of field performance data, notably temperature-coefficient data for the current-voltage (I-V) characteristics over all irradiance levels encountered in the field. Generally, temperature coefficient and performance data are available only in a restricted range of illumination around 1-sun intensity. In this paper, the I-V performance data are presented, analyzed, and parameterized across a wide range of illumination levels and temperatures, allowing the modeling of the performance for three polycrystalline PV technologies: cadmium telluride, copper indium diselenide, and polycrystalline silicon. The data are scrutinized for clearsky and diffuse-illumination conditions.
\end{abstract}

\section{INTRODUCTION}

The prevalence of crystalline and polycrystalline silicon technologies (bulk-Si) may be ascribed to many factors that translate to overall comfort of PV integrators with bulk-Si technology. With thin films, in contrast, there is considerable unease in the industry for reasons including: lower efficiency, past failures, module-reliability issues, plus a general lack of field performance data and a dearth of temperature-coefficient data for thin-film modules [1]. Currently existing module-performance data, even for bulk-Si, tend to be quite limited, being available typically in a restricted range of illumination near 1 -sun. Furthermore, even much of the data presented at lower irradiance levels are generally obtained by attenuating the simulator intensity [2], which ignores angle-of-incidence or spectral effects present at lower illumination [3]; most likely, this thereby renders an unrealistic simulation of how lower light intensities affect the I-V parameters. In this paper, the I-V performance for polycrystalline thin-film PV modules is parameterized based on outdoor measurements, and a set of closed-form parameters and formulae are presented from which these can be translated to a wide variation of conditions.

\section{METHOD}

Outdoor performance data for three distinct PV technologies are scrutinized: three cadmium telluride ( $\mathrm{CdTe}$ ) modules (A, B, C); two copper indium diselenide (CIS) modules ( $A, B)$, and two polycrystalline silicon ( $\mathrm{pc}-\mathrm{Si}$ ) modules (A, B). Their I-V characteristics are analyzed: the behavior of the open-circuit voltage $\left(V_{o c}\right)$, short-circuit current $\left(I_{s c}\right)$, fill factor $(F F)$, and their respective temperature coefficients are derived from outdoor measurements, for irradiance levels ranging from low $\left(50 \mathrm{~W} / \mathrm{m}^{2}\right)$ to high $(1200$ $\mathrm{W} / \mathrm{m}^{2}$ ), with module temperatures ranging $20^{\circ}-65^{\circ} \mathrm{C}$. Irradiance levels were measured with a broadband pyranometer mounted in the same plane-of-array and angle as the modules; the temperatures represent back-ofmodule measurements; both are sampled simultaneously with the I-V traces. The featured modules are deployed facing south at fixed latitude tilt on the Performance and Energy Ratings Testbed (PERT) on the roof of the Outdoor Test Facility at NREL. The scrutinized data were obtained from 4 years worth of records, representing 30,000 to $50,000 \mathrm{I}-\mathrm{V}$ traces for each module. The $\mathrm{V}_{\mathrm{oc}}, \mathrm{I}_{\mathrm{sc}}$, and FF data, plus their temperature derivatives, were subsequently fit, evaluated at $25^{\circ} \mathrm{C}$, and parameterized as polynomial functions of irradiance. Additionally, the data were segregated for clear-sky and diffuse illumination conditions using a statistical filter and model. All the parameters needed to calculate module performance for a wide range of operating conditions are presented.

One approach to modeling module performance is to interpolate the I-V trace at arbitrary irradiance in terms of traces already measured at nearby values [4]. However, this involves some recursive evaluation, does not represent a closed-form approach, and it may not be clear which are the best traces to use. Another approach is to extend the definition of the temperature coefficientsdefined as the derivative with respect to temperature of the I-V parameter in question divided by its value at standard test conditions (STC) - to cover that of the derivatives measured at other irradiance, with these divided by the parameter's value at the new irradiance and $25^{\circ} \mathrm{C}$. Note that even though the temperature derivatives of the I-V parameters might be slowly varying functions of irradiance, when these are divided by the respective parameter values at $25^{\circ} \mathrm{C}$ at the same irradiance, the resulting coefficient is convoluted with complex irradiance dependence. Hence, one problem that is encountered in expressing module performance in closed-form is formulating the dependence of the I-V parameters themselves.

In its simplest form, a PV device is modeled via the diode equation with parasitic series- and shunt-resistance terms. Deriving irradiance and temperature dependence for the I-V parameters $\left(I_{s c}, V_{o c}\right.$, and FF) is fairly complex when parasitic resistances are taken into account, the details of which calculations can be found in the literature [5]. This reference points out the dependence of the FF on the reciprocal $V_{o c}$, which translates to a logarithmic dependence with irradiance. In this analysis, the I-V parameters and their temperature derivatives were reduced and evaluated at $25^{\circ} \mathrm{C}$ module temperature across varying 
irradiance in $50 \mathrm{~W} / \mathrm{m}^{2}$-wide discrete intervals thereof. The data are subsequently fit to a polynomial function in powers of irradiance, or its logarithm. One to three such terms were employed in the fits, containing 17-23 evaluations spanning irradiance values $50-1200 \mathrm{~W} / \mathrm{m}^{2}$. The number of fitting terms was limited to three, with the criteria for keeping terms based on statistical significance using the FDistribution test at the $99 \%$ level of confidence.

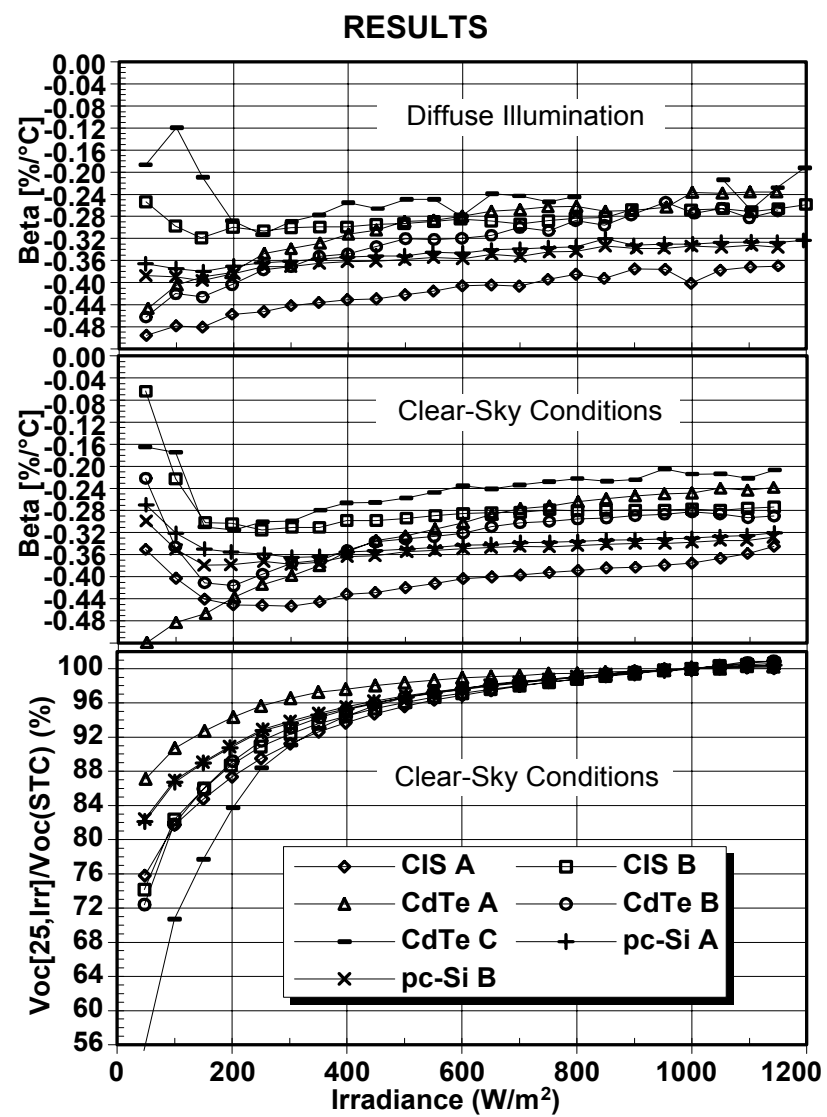

Fig. 1. $\mathrm{V}_{\text {oc }}$ data at $25^{\circ} \mathrm{C}$ and varying irradiance relative to values at STC at bottom, and beta values at middle, plotted against irradiance for 7 modules, for clear-sky conditions. Beta values at top are for diffuse illumination data.

Figure 1 depicts the ratio of module $\mathrm{V}_{\mathrm{oc}}$ at $25^{\circ} \mathrm{C}$ across varying illumination as ratios to values at STC and its temperature coefficients, beta, respectively, in bottom and middle portions of the graph, plotted against irradiance along the ordinate axis, for predominantly clear-sky data. At top, the beta for diffuse illumination is depicted. Beta is defined as the derivative of $V_{o c}$ with respect to temperature evaluated at a given irradiance, divided by the value $\mathrm{V}_{\mathrm{oc}}$ at $25^{\circ} \mathrm{C}$ and the same irradiance. At $1000 \mathrm{~W} / \mathrm{m}^{2}$, beta values range from $-0.28 \%$ to $-0.20 \%$ per ${ }^{\circ} \mathrm{C},-0.28 \%$ to $-0.40 \%$ per ${ }^{\circ} \mathrm{C}$, and $-0.35 \%$ per ${ }^{\circ} \mathrm{C}$, respectively, for $\mathrm{CdTe}, \mathrm{CIS}$, and pc-Si modules. The values of beta for clear-sky data become larger, more negative-about 25\% larger-toward lower irradiance at $200 \mathrm{~W} / \mathrm{m}^{2}$. Thereafter, they appear to increase toward positive direction while still remaining negative down to $50 \mathrm{~W} / \mathrm{m}^{2}$ irradiance. There are slight differences between clear-sky and diffuse data, except at the lowest irradiance.

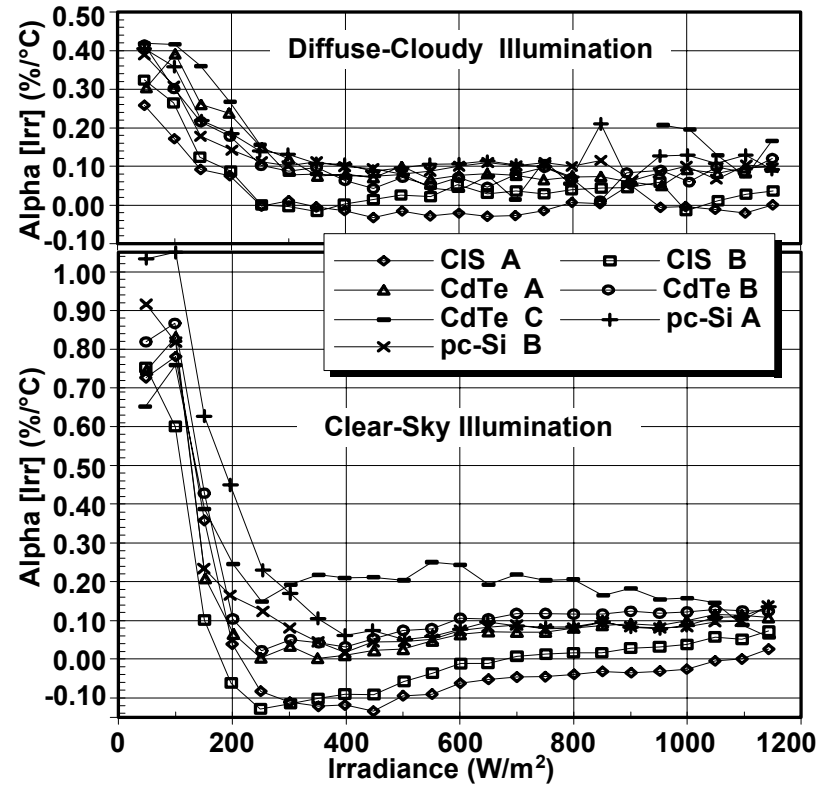

Fig. 2. Temperature coefficients of $\mathrm{I}_{\mathrm{sc}}$, alpha, plotted vs. irradiance for predominantly diffuse (top) and clear (bottom) conditions for seven polycrystalline PV modules.

In Fig. 2, the coefficients alpha are depicted for predominantly diffuse- and clear-sky illumination conditions, respectively, at top and bottom portions of the graph, plotted against irradiance along the ordinate axis. Alpha is defined as the derivative with respect to temperature of $\mathrm{I}_{\mathrm{sc}}$ at a given irradiance divided by $\mathrm{I}_{\mathrm{sc}}$ at $25^{\circ} \mathrm{C}$ and the same irradiance. If instead, alpha were defined as the derivative divided by the value of $\mathrm{I}_{\mathrm{sc}}$ at STC, then the alpha values at low irradiance do not exhibit the increase depicted in Fig. 2. A striking feature of the data in Fig. 2 is the substantial difference between the two data sets at low illumination, below $250 \mathrm{~W} / \mathrm{m}^{2}$ irradiance: for diffuse illumination, the data do not exhibit as pronounced an increase as for the clear-sky data. Otherwise, above $300 \mathrm{~W} / \mathrm{m}^{2}$ irradiance, the alpha values between sets are quite similar, except for one of the CdTe modules (CdTe C). Also note that for the CIS modules under some irradiance conditions, the alpha values become negative. This behavior was observed for this module when measured under the Spire simulator.

Figure 3 portrays the FF data at $25^{\circ} \mathrm{C}$ under varying illumination, as ratios of their values at STC, and its temperature coefficients, respectively, in bottom and top portions of the graph, plotted against irradiance, for predominantly clear-sky conditions. Except for CdTe A, all the FF data vary smoothly in going from high to low illuminationtypically exhibiting slight increases initially as the irradiance decreases, and then decreasing toward low irradiance. This behavior is consistent with series-resistance losses at high irradiance that become smaller at lower irradiance; and then by the functional dependence with $\mathrm{V}_{\text {oc }}$, series and shunt resistance at low irradiance [5]. With the one exception (CdTe A), the temperature coefficients of the FF show monotonically decreasing values with increasing irradiance, varying from small positive values to negative values in the range $200-500 \mathrm{~W} / \mathrm{m}^{2}$. For diffuse illumination data, the FF and temperature coefficients are similar to those depicted in Fig. 3, except for CdTe A. 


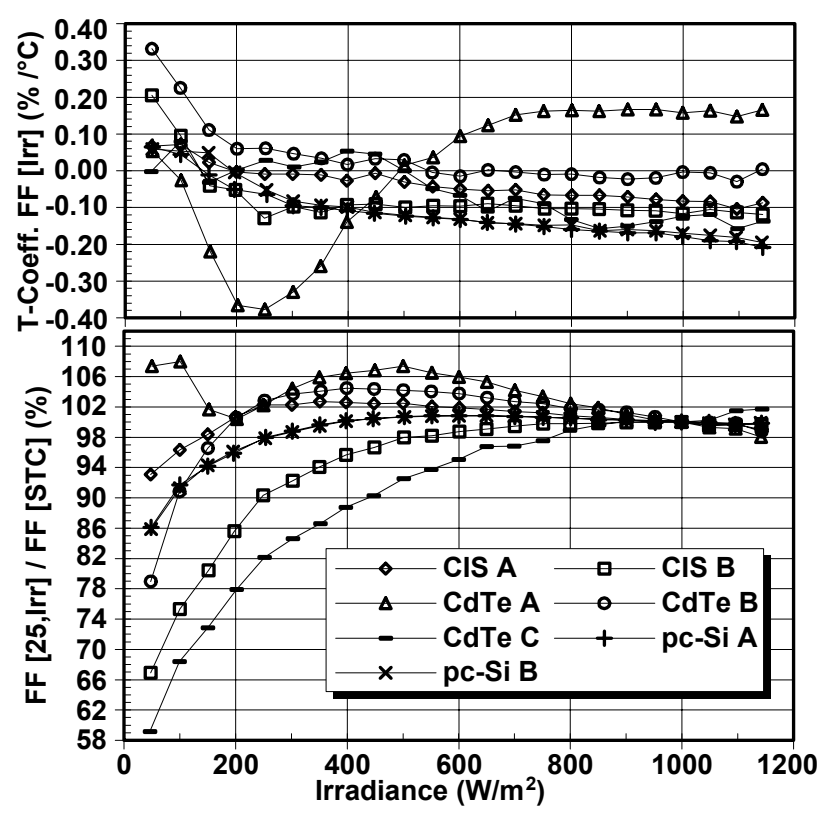

Fig. 3. FF ratios at $25^{\circ} \mathrm{C}$ relative to values at STC at bottom and its temperature coefficients at top, plotted against irradiance for seven modules, for clear-sky conditions.

For CdTe A, the FF behavior below $600 \mathrm{~W} / \mathrm{m}^{2}$ irradiance is complex, but likely to be real as each point represents 500 to $700 \mathrm{I}-\mathrm{V}$ traces. In contrast, for diffuse illumination, the FF and temperature coefficients do not show the complex behavior seen at low irradiance in Fig. 3. Instead, the FF values increase at low irradiance and reach $110 \%$ of the value at STC at $\sim 100 \mathrm{~W} / \mathrm{m}^{2}$. Its temperature coefficients obey a monotonic increase in values with irradiance, exhibiting nearly identical values to those shown in Fig. 3 for irradiance above $600 \mathrm{~W} / \mathrm{m}^{2}$.

\section{ANALYSIS}

Parametric representations for $\mathrm{V}_{\mathrm{oc}}, \mathrm{I}_{\mathrm{sc}}$, FF data plus their temperature coefficients beta, alpha, and Tcoeff FF are tabulated in the next section: Tables $1-6$ and 7-12, respectively, for clear-sky and diffuse lighting. In these tables, the first, second, and third columns, respectively, denote the module, respective parameter value at STC, and one standard deviation of the fit. For $V_{o c}, I_{s c}$, and FF, the fourth and higher columns represent the coefficients of the terms $\left(c_{i}\right)$ expressed as ratios of their STC values. For the temperature coefficients, the fourth and higher columns are simply the values of the coefficients of the fitting terms. The specific functional terms in the irradiance used are listed along the top row of each column, where the fourth column is the constant term, the fifth is the logarithm, the sixth is the linear, etc., as terms of the irradiance expressed in $\mathrm{W} / \mathrm{m}^{2}$. All the values of the temperature coefficients are evaluated as $\%$ change per ${ }^{\circ} \mathrm{C}$ with respect to the parameter evaluated at $25^{\circ} \mathrm{C}$, at the same irradiance. To calculate any I-V parameter, $\mathrm{P}(\mathrm{x})$, or its temperature coefficient $(\operatorname{Tcoeff}(x))$ at arbitrary irradiance, use Eqn. 1, with $P^{S T C}$ values taken from the second columns for $V_{o c}$, $\mathrm{I}_{\mathrm{sc}}$, and FF, and with $\mathrm{P}^{\mathrm{STC}}=1$ for the temperature coefficients; and with $x=$ irradiance expressed in units of $\mathrm{W} / \mathrm{m}^{2}$. Subsequently, to calculate the values of $\mathrm{V}_{\mathrm{oc}}, \mathrm{I}_{\mathrm{sc}}$, or $\mathrm{FF}$ at realistic module temperature $\mathrm{T}$, multiply the $P(x)$ by the temperature coefficient times the difference $\left(T-25^{\circ} \mathrm{C}\right)$ as per Eqn. 2. The $V_{o c}, I_{s c}$, and FF are formulated such that their respective values at STC multiply a unitless function of irradiance inside the braces in Eqn. 1, which could accommodate similar modules simply by using their values at STC, rather than the ones studied.

$$
\begin{gathered}
P(x)=P^{S T C} \cdot\left\{c_{0}+c_{L} \operatorname{Ln}(x)+c_{1} x+c_{2} x^{2}+c_{3} x^{3}+c_{-1} / x+c_{-2} / x^{2}\right\} \\
P(x, T)=P(x) \cdot\{1+\operatorname{Tcoeff}(x) \cdot[T-25]\}
\end{gathered}
$$

More elaborate parameterization terms are used to represent $\mathrm{I}_{\mathrm{sc}}$ due to complex behavior in low-illumination situations, with differences between clear-sky and diffuse lighting. For clear-sky data, the fit contains log and quadratic terms - not usually associated with the formulation of $\mathrm{I}_{\mathrm{sc}}$-whereas for diffuse data, these terms are missing (except for CdTe A). The source of the complexity lies in how low-illumination situations arise. For clear-sky conditions, this occurs when the angle-of-incidence (AOI) between the sun and the modules' surfaces is large and the direct-beam component becomes increasingly reflected and less absorbed. Diffuse illumination occurs either from obscuration by clouds or from lighting coming chiefly from the sky dome. It is instructive to analyze the effect that $\mathrm{AOI}$ has on $\mathrm{I}_{\mathrm{sc}}$ via the photoresponse, which is defined as the short-circuit current density divided by the irradiancea quantity that is independent of area with units of $\mathrm{mA} / \mathrm{W}$. These data are depicted in Fig. 5 plotted vs. AOI for six of the modules, along with the average irradiance at those $\mathrm{AOI}$. When $\mathrm{I}_{\mathrm{sc}}$ is strictly linear with irradiance, the photoresponse is constant: this is borne out at $\mathrm{AOI}<60^{\circ}$. With increasing $\mathrm{AOI}$, the direct-beam component is reflected away more rapidly than the pyranometer's response drops off, with the net effect that the modules do not absorb this measurable energy and the photoresponse decreases. Above $\sim 84^{\circ} \mathrm{AOI}$, more of the irradiance under clear skies becomes diffuse and behaves as if it were coming from the sky dome at an average $\mathrm{AOI} \sim 45^{\circ}$, thus becoming less reflected, increasing the photoresponse, and convoluting the function for $I_{\mathrm{sc}}$.

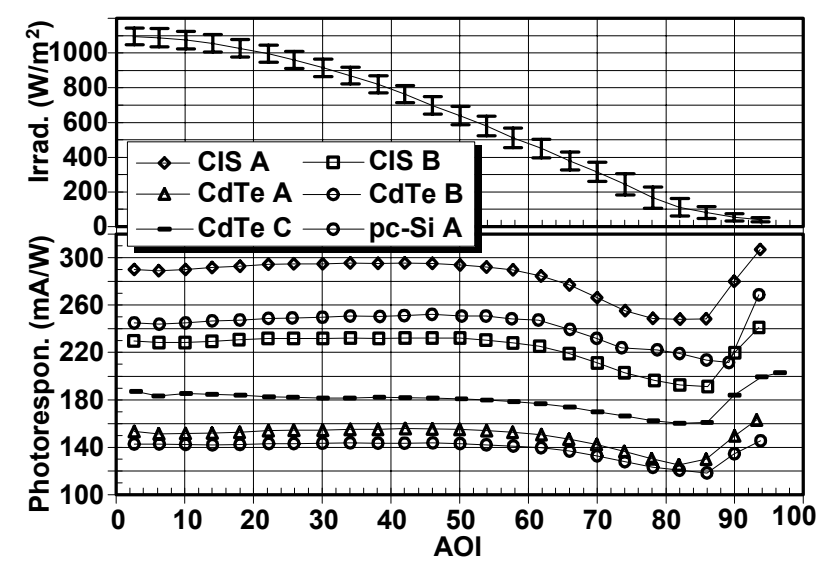

Fig. 5 Photoresponse at $25^{\circ} \mathrm{C}$ and irradiance plotted vs. AOI, respectively, at bottom and top for clear-sky data. 


\section{PARAMETRIC REPRESENTATION}

Table 1. $V_{o c}$ Parametric Representation $\left[25^{\circ} \mathrm{C}, \mathrm{x}=\right.$ irradiance], Clear-Sky Conditions.

\begin{tabular}{|c|c|c|c|c|c|c|c|}
\hline Module & $\mathrm{V}_{\text {oc }}^{\text {STC }}(\mathrm{V})$ & $\sigma(\mathrm{V})$ & $\mathrm{C}_{0} / \mathrm{V}_{\mathrm{oc}}^{\mathrm{STC}}$ & $\mathrm{c}_{\mathrm{L}} / \mathrm{V}_{\mathrm{OC}}{ }^{\mathrm{STC}}: \operatorname{Ln}(\mathrm{x})$ & $\mathrm{C}_{1} / \mathrm{V}_{\mathrm{oc}}^{\mathrm{STC}}: \mathrm{x}^{1}$ & $\mathrm{c}_{2} / \mathrm{V}_{\mathrm{oc}}^{\mathrm{STC}}: \mathrm{x}^{2}$ & $\mathrm{C}_{3} / \mathrm{V}_{\mathrm{oc}}^{\mathrm{STC}}: \mathrm{x}^{3}$ \\
\hline CIS A & 25.468 & 0.0471 & 0.4194 & 0.08658 & & & $-1.744 \mathrm{E}-11$ \\
\hline $\mathrm{CISB}$ & 54.142 & & & & $-6.885 \mathrm{E}-05$ & & \\
\hline CdTe A & 86.408 & & & & $\frac{E-05}{=05}$ & & \\
\hline CdTe B & 88.585 & 0.3716 & 0. & 0.11882 & $-9.597 \mathrm{E}-05$ & & \\
\hline CdTe C & 40.389 & & & 0.20602 & & $-4.159 \mathrm{E}-07$ & $2.303 \mathrm{E}-10$ \\
\hline pc-SiA & $\frac{21.487}{21.20}$ & 0.0216 & 0.5730 & 0.06379 & & $-1.366 \mathrm{E}-08$ & \\
\hline pc-Si B & 21.369 & 0.0262 & 0.5768 & 0.06348 & & $-1.528 \mathrm{E}-08$ & \\
\hline
\end{tabular}

Table 2. $I_{\mathrm{sc}}$ Parametric Representation $\left[25^{\circ} \mathrm{C}, \mathrm{x}=\right.$ irradiance], Clear-Sky Conditions.

\begin{tabular}{|c|c|c|c|c|c|c|}
\hline Module & $\mathrm{I}_{\mathrm{SC}}^{\mathrm{STC}}(\mathrm{A})$ & $\sigma(\mathrm{A})$ & $\mathrm{C}_{0} / \mathrm{I}_{\mathrm{SC}}^{\mathrm{STC}}$ & $\mathrm{C}_{\mathrm{L}} / \mathrm{I}_{\mathrm{SC}}{ }^{\mathrm{STC}}: \operatorname{Ln}(\mathrm{x})$ & $\mathrm{c}_{1} / \mathrm{I}_{\mathrm{SC}}^{\mathrm{STC}}: \mathrm{x}^{1}$ & $\mathrm{c}_{2} / \mathrm{I}_{\mathrm{Sc}}^{\mathrm{STC}}: \mathrm{x}^{2}$ \\
\hline $\mathrm{CISA}$ & 2.3449 & 0.0090 & 0.2564 & -0.070144 & $1.461 \mathrm{E}-03$ & $-2.326 \mathrm{E}-07$ \\
\hline CIS B & 2.0024 & 0.0068 & 0.2367 & -0.065320 & 1.432E-03 & $-2.173 \mathrm{E}-07$ \\
\hline CdTe A & 0.9074 & 0.0033 & 0.2797 & -0.076025 & $1.513 \mathrm{E}-03$ & $-2.678 \mathrm{E}-07$ \\
\hline CdTe B & 0.8858 & 0.0024 & 0.2018 & -0.055979 & $1.371 \mathrm{E}-03$ & $-1.865 \mathrm{E}-07$ \\
\hline CdTe C & 2.8345 & 0.0137 & 0.1374 & -0.036841 & $1.188 \mathrm{E}-03$ & $-7.067 \mathrm{E}-08$ \\
\hline $\mathrm{pc}-\mathrm{Si} \mathrm{A}$ & 2.1995 & 0.0081 & 0.2389 & -0.065585 & $1.468 \mathrm{E}-03$ & $-2.542 \mathrm{E}-07$ \\
\hline pc-Si B & 2.1960 & 0.0081 & 0.2390 & -0.066055 & $1.476 \mathrm{E}-03$ & $-2.589 \mathrm{E}-07$ \\
\hline
\end{tabular}

Table 3. Fill Factor (FF) Parametric Representation $\left[25^{\circ} \mathrm{C}, \mathrm{x}=\right.$ irradiance], Clear-Sky Conditions.

\begin{tabular}{|c|c|c|c|c|c|c|c|c|c|}
\hline Module & $\mathrm{FF}^{\mathrm{STC}}(\%)$ & $\sigma(\%)$ & $\mathrm{c}_{0} / \mathrm{FF}^{\mathrm{STC}}$ & $C_{\mathrm{L}} / \mathrm{FF}^{\mathrm{STC}}: \mathrm{Ln}(\mathrm{x})$ & $\mathrm{c}_{1} / \mathrm{FF}^{\mathrm{STC}}: \mathrm{x}$ & $\mathrm{c}_{2} / \mathrm{FF}^{\mathrm{STC}}: \mathrm{x}^{2}$ & $\mathrm{c}_{3} / \mathrm{FF}^{\mathrm{STC}}: \mathrm{x}^{3}$ & $\mathrm{C}_{-1} / \mathrm{FF}^{\mathrm{STC}}: 1 / \mathrm{x}$ & $\mathrm{C}_{-2} / \mathrm{FF}^{\mathrm{STC}}: 1 / \mathrm{x}^{2}$ \\
\hline $\mathrm{CISA}$ & 62.00 & 0.18 & 1.584 & -0.07967 & & & & -34.673 & 872.63 \\
\hline $\mathrm{CISB}$ & 70.66 & 0.32 & -0.221 & 0.21258 & $-2.481 \mathrm{E}-04$ & & & & 182.80 \\
\hline CdTe A & 57.27 & 1.11 & 1.039 & & $2.659 \mathrm{E}-05$ & & $-6.597 \mathrm{E}-11$ & & \\
\hline CdTe B & 52.71 & 0.40 & $\frac{1.058}{1.881}$ & -0.11980 & & & & -55.036 & 1181.59 \\
\hline CdTe C & 56.97 & 0.26 & -0.225 & 0.18449 & & $-5.436 \mathrm{E}-08$ & & 4.906 & \\
\hline pc-Si A & 73.82 & 0.18 & 0.524 & 0.08792 & $-1.314 \mathrm{E}-04$ & & & & \\
\hline $\mathrm{pc}-\mathrm{Si} B$ & 74.34 & 0.15 & 0.517 & 0.08917 & $-1.328 \mathrm{E}-04$ & & & & \\
\hline
\end{tabular}

Table 4. Beta Temperature-Coefficient Parametric Representation [ $25^{\circ} \mathrm{C}, \mathrm{x}=$ irradiance], Clear-Sky Conditions.

\begin{tabular}{|c|c|c|c|c|c|c|c|c|}
\hline Module & beta $^{\mathrm{STC}}\left(\% /{ }^{\circ} \mathrm{C}\right)$ & $\sigma\left(\% /{ }^{\circ} \mathrm{C}\right)$ & $\mathrm{C}_{0}$ & $c_{L}: \operatorname{Ln}(x)$ & $C_{1}: x^{1}$ & $c_{2}: x^{2}$ & $c_{3}: x^{3}$ & $c_{-1}: 1 / x$ \\
\hline $\mathrm{CISA}$ & $-3.671 \mathrm{E}-03$ & 7.5348 E-05 & $-5.0413 E-03$ & & $1.298 \mathrm{E}-06$ & & & 0.07233 \\
\hline CIS B & $-2.754 \mathrm{E}-03$ & 6.4270 E-05 & $-4.4477 \mathrm{E}-03$ & & $2.991 \mathrm{E}-06$ & $-1.474 \mathrm{E}-09$ & & 0.17667 \\
\hline CdTe A & $-2.457 \mathrm{E}-03$ & 4.4782 E-05 & $-5.4159 \mathrm{E}-03$ & & $5.648 \mathrm{E}-06$ & -2.689E-09 & & \\
\hline CdTe C & $-2.117 \mathrm{E}-03$ & $1.9973 \mathrm{E}-04$ & 5.1144E-03 & $-1.820 \mathrm{E}-03$ & $8.945 \mathrm{E}-06$ & $-3.603 \mathrm{E}-09$ & & \\
\hline pc-Si A & $-3.266 \mathrm{E}-03$ & 3.5330 E-05 & $-3.8843 E-03$ & & & $1.379 \mathrm{E}-09$ & $-8.198 \mathrm{E}-13$ & 0.05860 \\
\hline pc-Si B & $-3.349 \mathrm{E}-03$ & 3.8321 E-05 & $-4.3989 \mathrm{E}-03$ & & $1.731 \mathrm{E}-06$ & $-7.463 \mathrm{E}-10$ & & 0.06513 \\
\hline
\end{tabular}

Table 5. Alpha Temperature-Coefficient Parametric Representation $\left[25^{\circ} \mathrm{C}, \mathrm{x}=\right.$ irradiance], Clear-Sky Conditions.

\begin{tabular}{|c|c|c|c|c|c|c|}
\hline Module & alpha $^{\text {STC }}\left(\% /{ }^{\circ} \mathrm{C}\right)$ & $\sigma\left(\% /{ }^{\circ} \mathrm{C}\right)$ & $\mathrm{C}_{0}$ & $c_{L}: \operatorname{Ln}(x)$ & $c_{-1}: 1 / x$ & $c_{-2}: 1 / x^{2}$ \\
\hline $\mathrm{CISA}$ & $8.915 \mathrm{E}-05$ & 4.5082 E-04 & $-5.2416 \mathrm{E}-02$ & 7.071E-03 & 3.767 & -106.21 \\
\hline CIS B & $6.840 \mathrm{E}-04$ & 5.4406 E-04 & $-4.4044 \mathrm{E}-02$ & $6.087 \mathrm{E}-03$ & 2.749 & -67.06 \\
\hline CdTe A & $1.226 \mathrm{E}-03$ & 6.6722 E-04 & $-4.3573 \mathrm{E}-02$ & $6.050 \mathrm{E}-03$ & 3.093 & -85.62 \\
\hline CdTe B & $1.400 \mathrm{E}-03$ & 6.2247 E-04 & $-4.1258 \mathrm{E}-02$ & $5.742 \mathrm{E}-03$ & 3.079 & -84.66 \\
\hline CdTe C & $1.387 \mathrm{E}-03$ & 7.5610 E-04 & $7.5033 \mathrm{E}-04$ & & 0.654 & -17.38 \\
\hline $\mathrm{pc}-\mathrm{Si} \mathrm{A}$ & 1.094E-03 & $2.2339 \mathrm{E}-04$ & $-4.0156 \mathrm{E}-02$ & $5.468 \mathrm{E}-03$ & 3.582 & -105.03 \\
\hline pc-Si B & 1.153E-03 & 5.4992 E-04 & $-3.4441 \mathrm{E}-02$ & 4.789E-03 & 2.582 & -66.09 \\
\hline
\end{tabular}

Table 6. FF Temperature-Coefficient Parametric Representation $\left[25^{\circ} \mathrm{C}, \mathrm{x}=\right.$ irradiance], Clear-Sky Conditions.

\begin{tabular}{|c|c|c|c|c|c|c|c|c|c|}
\hline Module & Tcoeff-FF $^{\text {STC }}\left(\% /{ }^{\circ} \mathrm{C}\right)$ & $\sigma(\%)$ & $\mathrm{C}_{0}$ & $C_{L}: \operatorname{Ln}(x)$ & $c_{1}: x^{1}$ & $c_{2}: x^{2}$ & $c_{3}: x^{3}$ & $C_{-1}: 1 / x$ & $c_{-2}: 1 / x^{2}$ \\
\hline $\mathrm{CISA}$ & $-8.282 \mathrm{E}-04$ & & $2.517 \mathrm{E}-03$ & $-4.508 \mathrm{E}-04$ & & $-2.313 \mathrm{E}-10$ & & & \\
\hline $\mathrm{CISB}$ & $-1.079 \mathrm{E}-03$ & & $-1.502 \mathrm{E}-03$ & & $2.455 \mathrm{E}-07$ & & & 0.1777 & \\
\hline CdTe A & $1.925 \mathrm{E}-03$ & $E-04$ & & $-7.386 \mathrm{E}-03$ & $4.504 \mathrm{E}-05$ & $-2.001 \mathrm{E}-08$ & & & \\
\hline CdTe B & $-4.031 \mathrm{E}-04$ & 4. & $-5.568 \mathrm{E}-05$ & & & & $-5.186 \mathrm{E}-13$ & 0.1711 & \\
\hline $\mathrm{CdTe} 0$ & $-1.361 E-03$ & & & & $-1.987 \mathrm{E}-06$ & & & & \\
\hline$\frac{\mathrm{pc}-\mathrm{SiA}}{\mathrm{pc}-\mathrm{SiB}}$ & $\begin{array}{l}\frac{-1.795 E-03}{-1727 E-03} \\
\end{array}$ & $\frac{8.31 \mathrm{E}-05}{104 \mathrm{E}-04}$ & $\frac{2.124 \mathrm{E}-03}{9449 \mathrm{E}-04}$ & $\begin{array}{l}-5.869 \mathrm{E}-04 \\
-4255 \mathrm{E}-04\end{array}$ & & & & $\begin{array}{ll}0.1404 \\
0.2784\end{array}$ & \begin{tabular}{r|}
-4.893 \\
-10.504 \\
\end{tabular} \\
\hline
\end{tabular}

Table 7. $V_{o c}$ Parametric Representation $\left[25^{\circ} \mathrm{C}, \mathrm{x}=\right.$ irradiance], Diffuse-Illumination Conditions.

\begin{tabular}{|c|c|c|c|c|c|c|c|}
\hline Module & $\mathrm{V}_{\mathrm{oc}}^{\text {STC }}(\mathrm{V})$ & $\sigma(\mathrm{V})$ & $\mathrm{C}_{0} / \mathrm{V}_{\mathrm{oc}}^{\mathrm{STC}}$ & $\mathrm{C}_{\mathrm{L}} / \mathrm{V}_{\text {oc }}{ }^{\mathrm{STC}}: \operatorname{Ln}(\mathrm{x})$ & $\mathrm{c}_{1} / \mathrm{V}_{\mathrm{oc}}{ }^{\mathrm{STC}}: \mathrm{x}^{1}$ & $\mathrm{C}_{-1} / \mathrm{V}_{\mathrm{oc}}{ }^{\mathrm{STC}}: 1 / \mathrm{x}$ & $\mathrm{C}_{-2} / \mathrm{V}_{\mathrm{oc}}^{\mathrm{STC}}: 1 / \mathrm{x}^{2}$ \\
\hline $\operatorname{CISA}$ & 25.514 & 0.0570 & 0.1271 & 0.0259 & $-1.095 \mathrm{E}-05$ & & \\
\hline & $\frac{54.038}{86.319}$ & $\begin{array}{l}0.1053 \\
0.1295 \\
\end{array}$ & & $\frac{0.04360}{0.05225}$ & & -5.616 & \\
\hline CdTe & 88.423 & & & & & -7.533 & \\
\hline CdTe C & 40.420 & 0.10 & & & $-1.721 \mathrm{E}-04$ & & -186. \\
\hline$\frac{\mathrm{pc}-\mathrm{Si} A}{\mathrm{pc}-\mathrm{Si} \mathrm{E}}$ & $\frac{21.482}{21.376}$ & \begin{tabular}{l|l}
0.0183 \\
0.0204
\end{tabular} & \begin{tabular}{l|}
0.7024 \\
0.7007
\end{tabular} & 0.04340 & & $\begin{array}{l}-2.192 \\
-2057\end{array}$ & \\
\hline
\end{tabular}


Table 8. $\mathrm{I}_{\mathrm{sc}}$ Parametric Representation $\left[25^{\circ} \mathrm{C}, \mathrm{x}=\right.$ irradiance], Diffuse-Illumination Conditions.

\begin{tabular}{|r|r|r|r|r|r|r|}
\hline Module & $\mathrm{V}_{\text {oc }}{ }^{\text {STC }}(\mathrm{V})$ & $\sigma(\mathrm{V})$ & \multicolumn{1}{c|}{$\mathrm{C}_{0} / \mathrm{V}_{\text {oc }}{ }^{\text {STC }}$} & $\mathrm{C}_{\mathrm{L}} / \mathrm{V}_{\text {oc }}{ }^{\text {STC }}: \mathrm{Ln}(\mathrm{x})$ & $\mathrm{C}_{1} / \mathrm{V}_{\text {oc }}{ }^{\text {STC }}: \mathrm{x}^{1}$ & $\mathrm{C}_{3} / \mathrm{V}_{\text {oc }}{ }^{\text {STC }}: \mathrm{x}^{3}$ \\
\hline ClS A & 2.3322 & 0.0106 & 0.00236 & & $1.012 \mathrm{E}-03$ & $-1.472 \mathrm{E}-11$ \\
\hline ClS B & 2.0032 & 0.0106 & -0.00146 & & $1.015 \mathrm{E}-03$ & $-1.365 \mathrm{E}-11$ \\
\hline CdTe A & 0.9126 & 0.0038 & 0.07805 & -0.018616 & $1.099 \mathrm{E}-03$ & $-4.841 \mathrm{E}-11$ \\
\hline CdTe B & 0.8923 & 0.0058 & 0.00350 & & $9.965 \mathrm{E}-04$ & \\
\hline CdTe C & 2.8777 & 0.0151 & 0.00267 & & $9.973 \mathrm{E}-04$ & \\
\hline pc-Si A & 2.2028 & 0.0116 & 0.00685 & & $1.009 \mathrm{E}-03$ & $-1.616 \mathrm{E}-11$ \\
\hline pc-Si B & 2.2029 & 0.0090 & 0.00352 & & $1.017 \mathrm{E}-03$ & $-2.047 \mathrm{E}-11$ \\
\hline
\end{tabular}

Table 9. Fill Factor Parametric Representation $\left[25^{\circ} \mathrm{C}, \mathrm{x}=\right.$ irradiance], Diffuse-Illumination Conditions.

\begin{tabular}{|c|c|c|c|c|c|c|c|}
\hline Module & $\mathrm{FF}^{\mathrm{STC}}(\%)$ & $\sigma(\%)$ & $\mathrm{c}_{0} / \mathrm{FF}^{\mathrm{STC}}$ & $\mathrm{c}_{\mathrm{L}} / \mathrm{FF}^{\mathrm{STC}}: \operatorname{Ln}(\mathrm{x})$ & $\mathrm{c}_{1} / \mathrm{FF}^{\mathrm{STC}}: \mathrm{x}$ & $\mathrm{C}_{2} / \mathrm{FF}^{\mathrm{STC}}: \mathrm{x}^{2}$ & $\mathrm{C}_{-1} / \mathrm{FF}^{\mathrm{STC}}: 1 / \mathrm{x}$ \\
\hline $\mathrm{CISA}$ & 61.66 & 0.24 & 0.632 & 0.0838 & $-2.562 \mathrm{E}-04$ & $4.551 \mathrm{E}-08$ & \\
\hline CIS B & 70.74 & 0.21 & 0.071 & 0.1595 & $-1.725 \mathrm{E}-04$ & & \\
\hline CdTe A & 57.16 & 0.31 & 1.148 & & $-1.446 \mathrm{E}-04$ & & -3.155 \\
\hline CdTe B & 52.46 & 0.47 & 1.122 & & $-1.071 \mathrm{E}-04$ & & -15.039 \\
\hline $\mathrm{CdTe} \mathrm{C}$ & 59.74 & 0.38 & 0.107 & 0.1172 & $8.340 \mathrm{E}-05$ & & \\
\hline $\mathrm{pc}-\mathrm{SiA}$ & 73.40 & 0.49 & 0.691 & 0.0600 & $-1.029 \mathrm{E}-04$ & & -2.384 \\
\hline $\mathrm{pc}-\mathrm{Si} B$ & 74.26 & 0.26 & 0.556 & 0.0827 & $-1.270 \mathrm{E}-04$ & & -0.563 \\
\hline
\end{tabular}

Table 10.Beta Temperature-Coefficient Parametric Representation $\left[25^{\circ} \mathrm{C}, \mathrm{x}=\right.$ irradiance], Diffuse-Illumination Conditions.

\begin{tabular}{|c|c|c|c|c|c|c|c|c|}
\hline Module & beta $^{\mathrm{STC}}\left(\% /{ }^{\circ} \mathrm{C}\right)$ & $\sigma\left(\% /{ }^{\circ} \mathrm{C}\right)$ & $\mathrm{C}_{0}$ & $c_{L}: \operatorname{Ln}(x)$ & $c_{1}: x$ & $c_{2}: x^{2}$ & $c_{-1}: 1 / x$ & $c_{-2}: 1 / x^{2}$ \\
\hline $\mathrm{CIS} \mathrm{A}$ & $-3.792 \mathrm{E}-03$ & $6.593 \mathrm{E}-05$ & $-8.029 \mathrm{E}-03$ & 0.000608 & & & 0.03566 & \\
\hline $\mathrm{CISB}$ & $-2.708 \mathrm{E}-03$ & $4.794 \mathrm{E}-05$ & $-3.196 \mathrm{E}-03$ & & $4.866 \mathrm{E}-07$ & & & 1.38084 \\
\hline CdTe A & $-2.488 \mathrm{E}-03$ & $8.467 \mathrm{E}-05$ & $-7.330 \mathrm{E}-03$ & 0.000701 & & & & \\
\hline CdTe B & $-2.773 \mathrm{E}-03$ & $1.339 \mathrm{E}-04$ & $-4.688 \mathrm{E}-03$ & & $3.736 \mathrm{E}-06$ & $-1.820 \mathrm{E}-09$ & & \\
\hline CdTe C & $-1.942 \mathrm{E}-03$ & $2.218 \mathrm{E}-04$ & $-2.006 \mathrm{E}-02$ & 0.002481 & & & 1.00600 & -28.00201 \\
\hline $\mathrm{pc}-\mathrm{Si} \mathrm{A}$ & $-3.286 \mathrm{E}-03$ & $3.397 \mathrm{E}-05$ & $-5.646 \mathrm{E}-03$ & 0.000337 & & & 0.03227 & \\
\hline $\mathrm{pc}-\mathrm{Si} \mathrm{B}$ & $-3.371 \mathrm{E}-03$ & $3.740 \mathrm{E}-05$ & $-5.732 \mathrm{E}-03$ & 0.000338 & & & 0.02556 & \\
\hline
\end{tabular}

Table 11.Alpha Temperature-Coefficient Parametric Representation [25 ${ }^{\circ} \mathrm{C}, \mathrm{x}=$ irradiance], Diffuse-Illumination Conditions.

\begin{tabular}{|r|r|r|r|r|r|r|r|}
\hline Module & alpha $^{\mathrm{STC}}\left(\% /{ }^{\circ} \mathrm{C}\right)$ & $\sigma\left(\% /{ }^{\circ} \mathrm{C}\right)$ & \multicolumn{1}{c|}{$\mathrm{C}_{0}$} & $\mathrm{C}_{\mathrm{L}}: \operatorname{Ln}(\mathrm{x})$ & $\mathrm{C}_{1}: \mathrm{x}$ & $\mathrm{C}_{-1}: 1 / \mathrm{x}$ & $\mathrm{C}_{-2}: 1 / \mathrm{x}^{2}$ \\
\hline CIS A & $-4.781 \mathrm{E}-05$ & $2.027 \mathrm{E}-04$ & $8.976 \mathrm{E}-03$ & -0.001684 & $2.607 \mathrm{E}-06$ & & \\
\hline CIS B & $3.668 \mathrm{E}-04$ & $2.484 \mathrm{E}-04$ & $-1.141 \mathrm{E}-02$ & 0.001584 & & 0.85674 & -21.293 \\
\hline CdTe A & $8.208 \mathrm{E}-04$ & $1.870 \mathrm{E}-04$ & $-1.223 \mathrm{E}-02$ & 0.001718 & & 1.22348 & -40.083 \\
\hline CdTe B & $6.931 \mathrm{E}-04$ & $3.241 \mathrm{E}-04$ & $1.186 \mathrm{E}-02$ & -0.002038 & $2.906 \mathrm{E}-06$ & & \\
\hline CdTe C & $1.764 \mathrm{E}-03$ & $3.099 \mathrm{E}-04$ & $4.330 \mathrm{E}-02$ & -0.007749 & $1.245 \mathrm{E}-05$ & -0.46201 & \\
\hline pc-Si A & $9.495 \mathrm{E}-04$ & $3.680 \mathrm{E}-04$ & $6.832 \mathrm{E}-04$ & & & 0.27144 & -5.089 \\
\hline pc-Si B & $9.496 \mathrm{E}-04$ & $1.736 \mathrm{E}-04$ & $-5.150 \mathrm{E}-03$ & 0.000806 & & 0.54502 & -12.441 \\
\hline
\end{tabular}

Table 12. FF Temperature-Coefficient Parametric Representation $\left[25^{\circ} \mathrm{C}, \mathrm{x}=\right.$ irradiance], Diffuse-Illumination Conditions.

\begin{tabular}{|c|c|c|c|c|c|c|c|c|}
\hline Module & Tcoeff-FF $^{\text {STC }}\left(\% /{ }^{\circ} \mathrm{C}\right)$ & $\sigma\left(\% /{ }^{\circ} \mathrm{C}\right)$ & $\mathrm{C}_{0}$ & $c_{L}: \operatorname{Ln}(x)$ & $c_{1}: x^{1}$ & $c_{2}: x^{2}$ & $c_{3}: x^{3}$ & $\mathrm{C}_{-1}: 1 / \mathrm{x}$ \\
\hline $\mathrm{CIS} \mathrm{A}$ & $-5.924 \mathrm{E}-04$ & $2.153 \mathrm{E}-04$ & $-5.924 \mathrm{E}-04$ & & & & & \\
\hline $\mathrm{CIS} \mathrm{B}$ & $-1.172 \mathrm{E}-03$ & 1.25 & $4.583 \mathrm{E}-04$ & -0.000241 & & & & 0.03215 \\
\hline CdTe A & $1.567 \mathrm{E}-03$ & $2.306 \mathrm{E}-04$ & $-1.148 \mathrm{E}-04$ & & $2.332 \mathrm{E}-06$ & & $-6.503 \mathrm{E}-13$ & \\
\hline CdTe B & $-2.516 \mathrm{E}-06$ & $3.641 \mathrm{E}-04$ & $1.016 \mathrm{E}-04$ & & & & $-1.758 \mathrm{E}-13$ & 0.07165 \\
\hline $\mathrm{CdTe} \mathrm{C}$ & $-2.991 \mathrm{E}-03$ & $4.820 \mathrm{E}-04$ & $1.714 \mathrm{E}-03$ & & $-4.706 \mathrm{E}-06$ & & & \\
\hline $\mathrm{pc}-\mathrm{Si} \mathrm{A}$ & $-1.732 \mathrm{E}-03$ & $2.878 \mathrm{E}-04$ & $3.299 \mathrm{E}-03$ & -0.000793 & $4.489 \mathrm{E}-07$ & & & \\
\hline pc-Si B & $-1.812 \mathrm{E}-03$ & $2.486 \mathrm{E}-04$ & $-9.084 \mathrm{E}-05$ & & $-3.848 \mathrm{E}-06$ & 2.127 & & \\
\hline
\end{tabular}

\section{CONCLUSIONS}

Parametric representations for $\mathrm{V}_{\mathrm{oc}}, \mathrm{I}_{\mathrm{sc}}, \mathrm{FF}$, and their temperature coefficients were presented in closed form for seven polycrystalline PV modules, from which these three primary I-V parameters and their temperature coefficients may be calculated for irradiance ranging from $50 \mathrm{~W} / \mathrm{m}^{2}$ to $1200 \mathrm{~W} / \mathrm{m}^{2}$, and for module temperatures ranging from $20^{\circ}-65^{\circ} \mathrm{C}$, for predominantly clear-sky and diffuseillumination conditions.

\section{ACKNOWLEDGEMENTS}

This work was supported by the U.S. Department of Energy under Contract No. DE-AC36-99G010337.

\section{REFERENCES}

[1] B. Hammond, "Thin-Film PV Technologies: A utility perspective," 3rd National Thin-Film Module Reliability Team Meeting, Albuquerque NM, Sept. 2003.

[2] B. Marion, B. Kroposki, K. Emery, J. del Cueto, D. Myers, and C. Osterwald, "Validation of a photovoltaic module energy ratings procedure at NREL," NREL Technical Report \# 520-26909, August 1999.

[3] R. Rüther, G. Kleiss, and K. Reichi, Solar Energy Materials and Solar Cells, 71, 2002, pp. 375-385.

[4] B. Marion, S. Rummel, and A. Anderberg, Progress in PV: Research and Applications, 12, 2004, pp. 1-16.

[5] de Vos, Solar Cells 8, 1983, pp. 283-296. 


\section{REPORT DOCUMENTATION PAGE}

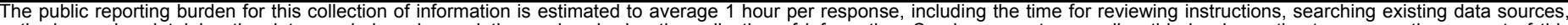

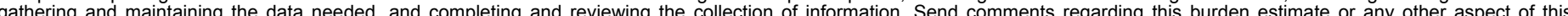

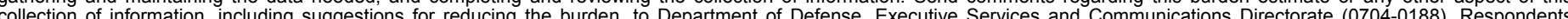

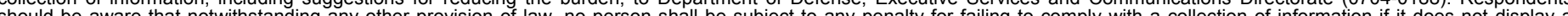

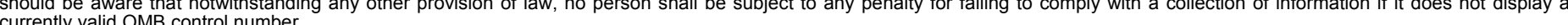

PLEASE DO NOT RETURN YOUR FORM TO THE ABOVE ORGANIZATION.

\section{REPORT DATE (DD-MM-YYYY) \\ February 2005}

4. TITLE AND SUBTITLE

Closed-Form Solutions and Parameterization of the Problem of

Current-Voltage Performance of Polycrystalline Photovoltaic

Modules Deployed at Fixed Latitude Tilt
3. DATES COVERED (From - To)

5a. CONTRACT NUMBER

DE-AC36-99-GO10337

5b. GRANT NUMBER

5c. PROGRAM ELEMENT NUMBER

5d. PROJECT NUMBER

NREL/CP-520-36565

5e. TASK NUMBER

PVB57101

5f. WORK UNIT NUMBER
7. PERFORMING ORGANIZATION NAME(S) AND ADDRESS(ES)

National Renewable Energy Laboratory

1617 Cole Blvd.

Golden, CO 80401-3393

9. SPONSORING/MONITORING AGENCY NAME(S) AND ADDRESS(ES)
8. PERFORMING ORGANIZATION REPORT NUMBER

NREL/CP-520-36565

10. SPONSOR/MONITOR'S ACRONYM(S) NREL

11. SPONSORING/MONITORING AGENCY REPORT NUMBER

\section{DISTRIBUTION AVAILABILITY STATEMENT}

National Technical Information Service

U.S. Department of Commerce

5285 Port Royal Road

Springfield, VA 22161

13. SUPPLEMENTARY NOTES

\section{ABSTRACT (Maximum 200 Words)}

One obstacle to wider market penetration for thin-film polycrystalline photovoltaic $(\mathrm{PV})$ modules is the lack of field performance data, notably temperature-coefficient data for the current-voltage (I-V) characteristics over all irradiance levels encountered in the field. Generally, temperature coefficient and performance data are available only in a restricted range of illumination around 1-sun intensity. In this paper, the I-V performance data are presented, analyzed, and parameterized across a wide range of illumination levels and temperatures, allowing the modeling of the performance for three polycrystalline PV technologies: cadmium telluride, copper indium diselenide, and polycrystalline silicon. The data are scrutinized for clear-sky and diffuse-illumination conditions.

\section{SUBJECT TERMS}

PV; thin-film; current-voltage (I-V); 1-sun intensity; cadmium telluride, copper indium diselenide; polycrystalline silicon; diffuseillumination;

\begin{tabular}{l}
\hline \multicolumn{3}{|l|}{ 16. SECURITY CLASSIFICATION OF: } \\
\hline \begin{tabular}{l|l|l|} 
a. REPORT & b. ABSTRACT & c. THIS PAGE \\
Unclassified & Unclassified & Unclassified \\
& & \\
\hline
\end{tabular} \\
\hline
\end{tabular}

\begin{tabular}{|l|l|} 
17. LIMITATION \\
OF ABSTRACT \\
UL
\end{tabular}

19a. NAME OF RESPONSIBLE PERSON

19b. TELEPHONE NUMBER (Include area code) 